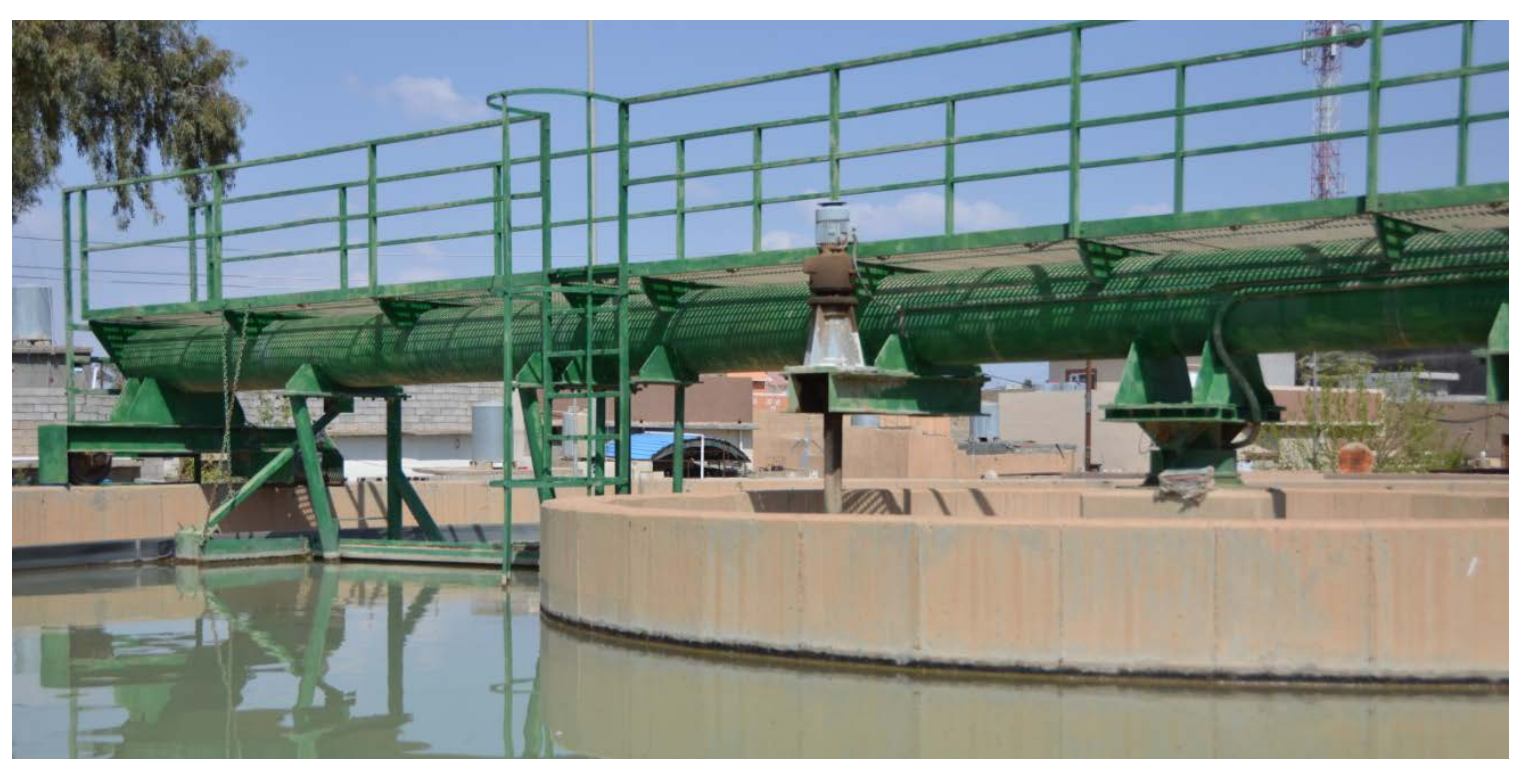

Oxfam rehabilitated water system in Qara Tapa, Iraq. Photo: Saleha Nisar/Oxfam.

\title{
THE CASE FOR IMPROVED WATER RESOURCE MANAGEMENT IN KIRKUK GOVERNORATE, IRAQ
}

\section{OXFAM IN IRAQ}

Iraq faces severe pressures on its water resources following years of conflict and under-investment in infrastructure. This report focuses on the state of water resources in Kirkuk governorate in the north of the country and identifies the main challenges that need to be addressed. In particular, it recommends a collaborative approach to water management between government, INGOs in the WASH sector and local communities and water users (including those involved in agriculture, industry and electricity generation). It is hoped that its recommendations will inform approaches to water management across the country as a whole and in the wider Middle East region.

Oxfam Research Reports are written to share research results, to contribute to public debate and to invite feedback on development and humanitarian policy and practice. They do not necessarily reflect Oxfam policy positions. The views expressed are those of the author and not necessarily those of Oxfam.
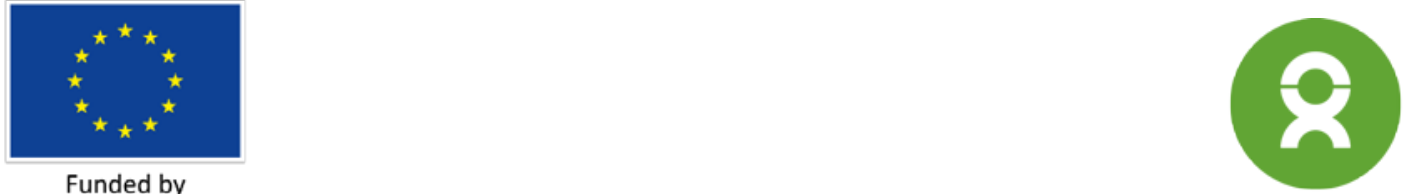


\section{CONTENTS}

Summary

1 Introduction $\quad 6$

2 Natural environment $\quad 8$

$3 \quad$ Institutions responsible for water resource management in Iraq 16

4 Why is water resource management in Iraq important? 19

5 Moving from ideas to action 25

$6 \quad$ Opportunities associated with water management 27

$\begin{array}{lll}7 & \text { Conclusions and next steps } & 28\end{array}$ 


\section{ACRONYMS}

DoW

Directorate of Water (Government of Iraq, Kirkuk)

DoS Directorate of Sewerage (Government of Iraq, Kirkuk)

FCAS Fragile and conflict-affected state

Gol Government of Iraq

IDP Internally displaced person

INGO International non-governmental organization

ISIS Islamic State of Iraq and Syria

IQD Iraqi dinar

KPC Kirkuk Provincial Council

KRG Kurdistan Regional Government

MDA Ministries, departments and agencies

MUS Multiple-use water system

NGO Non-governmental organization

UNESCO United Nations Educational, Scientific and Cultural Organization

WASH Water, sanitation and hygiene

WRA Water resource allocation

WRM Water resource management

WSP Water security planning 


\section{GLOSSARY OF TERMS}

\begin{tabular}{|c|c|}
\hline Community-based & $\begin{array}{l}\text { Referring to activities undertaken by, or with the participation of, local } \\
\text { communities. }\end{array}$ \\
\hline $\begin{array}{l}\text { Data, information } \\
\text { and knowledge }\end{array}$ & $\begin{array}{l}\text { Data are raw numbers derived from measurement or regular monitoring. When } \\
\text { data are processed and interpreted, they become information. When that } \\
\text { information is assimilated and used by individuals and organizations, it becomes } \\
\text { knowledge. }\end{array}$ \\
\hline Groundwater & $\begin{array}{l}\text { Groundwater refers to water below ground, held in saturated bodies of rock or } \\
\text { earth material. It can provide water to wells and boreholes. If the water table } \\
\text { intersects with the earth's surface, groundwater discharges naturally as spring } \\
\text { flow and river base flow. }\end{array}$ \\
\hline Hydrology & $\begin{array}{l}\text { Hydrology is the study, measurement and understanding of surface water flows. } \\
\text { Groundwater hydrology is the corresponding study of underground water. }\end{array}$ \\
\hline Hydrometeorology & $\begin{array}{l}\text { The study, measurement and understanding of surface and groundwater } \\
\text { hydrology, together with the meteorology on which water resources depend. }\end{array}$ \\
\hline $\begin{array}{l}\text { Improved/ } \\
\text { unimproved water } \\
\text { source }\end{array}$ & $\begin{array}{l}\text { Improved water sources are those that are engineered and protected in such a } \\
\text { way as to provide safe water, i.e. water free of, or low in, disease-causing } \\
\text { pathogens. Unimproved sources are unprotected from faecal contamination and } \\
\text { so pose a risk to human health. }\end{array}$ \\
\hline $\begin{array}{l}\text { Multiple-use water } \\
\text { system (MUS) }\end{array}$ & $\begin{array}{l}\text { Multiple-use water systems are low-cost, equitable water supply systems that } \\
\text { provide communities with water for both domestic needs and high-value } \\
\text { agricultural production, including rearing livestock. They are designed for use in } \\
\text { rural areas, inhabited by smallholder farmers, and generally cover ten to } 40 \\
\text { households, although some have served many more households }\end{array}$ \\
\hline $\begin{array}{l}\text { National monitoring } \\
\text { networks }\end{array}$ & $\begin{array}{l}\text { Networks of rain gauges, river flow stations and groundwater data points } \\
\text { designed to track the spatial and temporal distribution of a nation's water } \\
\text { resources. }\end{array}$ \\
\hline Wadi & A valley, ravine, or channel that is dry except in the rainy season. \\
\hline Water resources & $\begin{array}{l}\text { Water resources are the streams, rivers, surface water bodies and groundwater } \\
\text { stores which by their natural discharges support wetland ecosystems, and } \\
\text { which can be exploited for water supply for many purposes. }\end{array}$ \\
\hline Water security & $\begin{array}{l}\text { Water security means different things to different water users. However, the } \\
\text { common feature for all is the assurance of sufficient quantity and quality of } \\
\text { water for all the uses to which it is put. This, combined with low risk from } \\
\text { water-related hazards (floods and droughts), constitutes water security. }\end{array}$ \\
\hline $\begin{array}{l}\text { Water security } \\
\text { planning (WSP) }\end{array}$ & $\begin{array}{l}\text { Water security planning is a structured participative process involving risk } \\
\text { assessment, focused monitoring and action planning. It is an extension of the } \\
\text { more narrowly focused approach known as water safety planning. }\end{array}$ \\
\hline Water supply & $\begin{array}{l}\text { Water supply is the act of harnessing, engineering and managing the delivery of } \\
\text { water to users, for domestic, agricultural and industrial uses (including electricity } \\
\text { generation). }\end{array}$ \\
\hline
\end{tabular}




\section{SUMMARY}

Iraq's recent history has been violent and turbulent. This has fractured the country and created deep social divisions. Today, Iraq is a state in transition. It is trying to establish rule of law, strengthen democratic institutions and provide basic services. At the same time, pressures on the quantity and quality of its water resources are growing daily. Aside from major transboundary water management issues, abstractions for agriculture, mining, industry and hydroelectricity are all competing for a finite quantity of water. Discharges and effluents from all these uses and users threaten to pollute aquifers and watercourses, affecting other downstream users. As Iraq's population grows and its economy matures, these pressures will only increase.

This report brings together some perspectives on the state of water resources and basic services in Kirkuk governorate in the north of Iraq. It begins with an overview of the country's natural environment, before describing its institutional arrangements for managing water resources. It next discusses the current water situation in Kirkuk and distils the main problems that need to be addressed. It then goes on to examine the practical role that Oxfam and its partners can play in support of government and local institutions. Measures taken now could potentially mitigate some of the risks to Iraq's precious water resources.

The report highlights the fact that water resources in Kirkuk governorate are in a critical state. The war with Islamic State (ISIS) has destroyed water supply infrastructure in two of its four districts. The general perception is that basic services are in a state of decline, and there is a growing imbalance between water supply and demand. Supply is unreliable, with households in Kirkuk city receiving water only every two days. Only 16 percent of the urban population are connected to a public sewerage system. ${ }^{1}$ Industrial waste, untreated sewage, landfill sites and fossil fuel combustion are contaminating water resources. Amid the ongoing crisis, unresolved political tensions and the centralization of power in Baghdad have led to severe underinvestment in regional water and sanitation services. Unresolved land claims and competing claims on water within the governorate are not being adequately addressed. This has occurred at a time when the local population has increased by 25 percent as a result of human displacement. It is also projected that by 2025 Iraq will not have enough water, of adequate quantity and acceptable quality, to meet its development requirements. Today only one of Kirkuk's four aquifers provides water suitable for human consumption. ${ }^{2}$

Meanwhile domestic consumers compete with agricultural and industrial users for water from the Lesser Zab River. Oxfam recognizes that it must engage in some form of water resource management to help address these problems. However, the feeling in Kirkuk is that humanitarian projects are small in scale and that they should evolve beyond emergency interventions. Consequently, the water, sanitation and hygiene (WASH) sector should consider wider environmental issues and plan accordingly. A key requirement is to define the main water management problems that need to be addressed and identify influential stakeholders to work with. Although there are many problems to address, the first step in managing water resources is to 'know what you have got' - in other words, to help monitor the resource so that water quantity and quality can be assessed. This approach will serve to inform decision making and build resilience. Over time it will also be necessary to respond quickly to problems and opportunities that arise. When it comes to the methods to apply, it is evident that a learning by doing' approach should be adopted. This will enable Oxfam to build its own internal capacity and will lend credibility to future advocacy campaigns. For wider water management problems, the recommendation is to focus initially on less contentious water management problems. This will encourage different water users to work in a collaborative manner, before looking at more problematic issues. 


\section{INTRODUCTION}

Historically, there has never been an outright war over water in Iraq, but access to and control of water resources is an issue of growing strategic importance. The country is fractured and the risk of opposing groups seeking to control water resources for their own gain is real. Rivers, dams, canals and water treatment plants have all been military targets in the past; water resources have been diverted or cut off and water supply networks have been destroyed. This has led to large-scale human suffering and the forced displacement of people. ${ }^{3}$

Today, groundwater and surface water resources in Kirkuk are facing increased pressures and constant change. Driving this change are demand- and supply-side pressures that include a growing population and expanding industry. In responding to these challenges, it is vital that sound water resource management approaches are established, supported and scaled up in the near future. Oxfam is one of the organizations working to deliver water, sanitation and hygiene (WASH) services in Kirkuk governorate. For example, between August 2015 and May 2016, it provided emergency WASH assistance to newly displaced populations in Kirkuk and Daquq. The programme was funded by the European Commission's Humanitarian Aid and Civil Protection department (ECHO).

This report explains why water resource management is important and points the way for possible interventions in Kirkuk. It describes Oxfam's current thinking on strengthening water security planning at local and national levels. ${ }^{4}$ It does not set out to address all water management problems, but rather it explains the supporting role that Oxfam and its development partners can play alongside the Kurdistan Regional Government (KRG) and the Government of Iraq (Gol). This document will therefore be of interest to practitioners involved in WASH activities and will also be useful for those institutions responsible for policy and strategy and the 'bigger picture' of water resources in Iraq.

At its heart is the recognition that Kirkuk is one of two governorates that is disputed in its entirety by the KRG and the Gol. ${ }^{5}$ The political problems come down to issues of national identity, as well as options for restructuring state power between the centre and the disputed territories. ${ }^{6}$ There will be strong opinions about the dynamics between the KRG and the Gol, but the main issue is to find common ground so that all sides are willing to share water resources in a fair manner. The development problems of real interest to citizens of Kirkuk governorate include growing water insecurity, as well as declining services for sanitation and agriculture.

In terms of methodology this report draws on an extensive literature review (including reports, journals and government and media websites) and field research undertaken by Oxfam. In March-April 2016, 36 separate interviews and seven focus group discussions (FGDs) were held across four sub-districts in Kirkuk. Meetings took place with representatives of a wide range of ethnic groups and ruling authorities, involving 128 participants in total. These included urban and rural communities, displaced people, members of host communities and representatives of the Kirkuk Provincial Council (KPC). Research questions explored the underlying political dynamics, the current water situation and perceptions of the standard of services. Broader questions about possible solutions and institutional roles and responsibilities for water resources management were also discussed. This research identified numerous common issues related to water security that need to be addressed. The research was funded by ECHO under the Emergency WASH Assistance to Newly Displaced Populations of Kirkuk Governorate project.

The main research activities undertaken outside Iraq were further background research and discussions with Oxfam staff in Iraq and regional technical advisors. Discussion participants reviewed the initial recommendations and suggested a series of activities that could be completed in the short to medium term. Note that the report recommends local level initiatives that could be examined and readjusted as the programme continues. A primary aim was the 
methodology was practical in nature so that it could be replicated elsewhere. This is an important consideration when working in conflict-affected areas.

However, the research also had some limitations, including limited access to remote rural communities as a result of ongoing violence and hostility. It was also difficult to track down historical monitoring data for Kirkuk. Thus, it appears that there is a good opportunity to encourage other international non-governmental organizations (INGOs) to engage in collecting hydrometric data. The wider water resource management priorities of central government also need to be explored. It is hoped that this report will stimulate interest in greater collaboration between central, regional and local authorities responsible for water security planning.

The report consists of seven sections, of which this introduction is the first. Section 2 examines Iraq's natural environment and describes the hydrological context in which water resource management must take place. Section 3 describes the institutional landscape and introduces the key institutions mandated to manage water resources. It also draws attention to the role of local institutions in managing communal water and land resources. Section 4 explains why water resource management is so important in Kirkuk, and provides an overview of the pressures and responses required to strengthen water management. Section 5 sets out how the WASH sector could play a meaningful role in monitoring and managing water resources. Section 6 describes potential opportunities for strengthening water resource management at local level, while section 7 provides final conclusions and recommendations.

\section{Figure 1: The Governorate of Kirkuk}

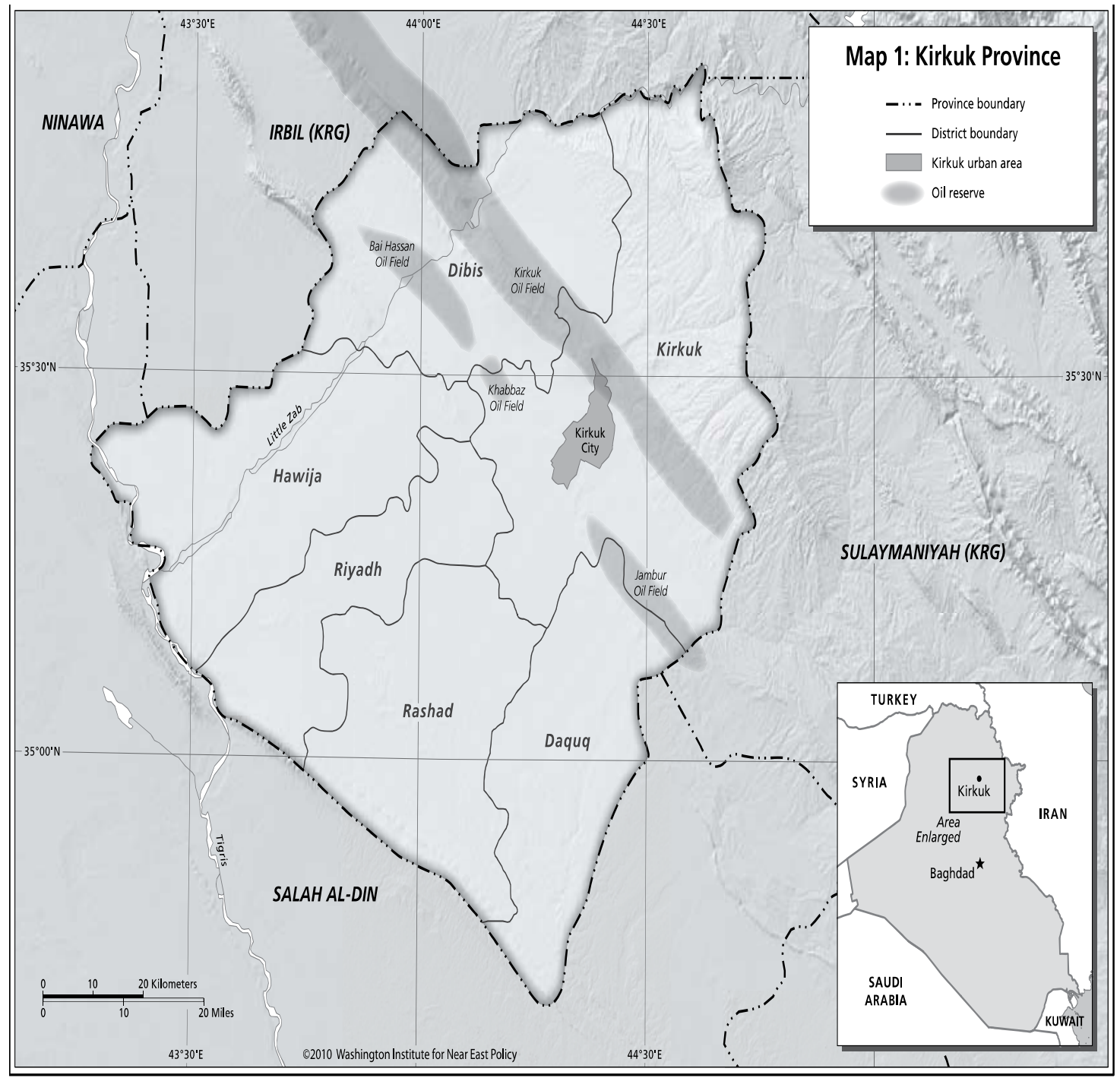

Source: M. Knights and A. Ali. (2010). Kirkuk in Transition: Confidence Building in Northern Iraq. 
This section describes Kirkuk's recent history and its natural environment, including rainfall, hydrogeology, surface water and water use. This information provides a context for the recommendations made later in the report.

\section{OVERVIEW}

Kirkuk's population consists of Kurds, Arabs, Turkmens and Assyrians. ${ }^{7}$ It has a long history of multi-ethnic relations, but it is also a territory disputed between the KRG and the Gol. It is unhelpful to favour one group's claims over those of another. For this reason, this report concentrates on Kirkuk's recent history and issues a plea for greater collaboration.

The fall of the Ba'athist regime in April 2003 reversed the political situation in Kirkuk. The Kurdish security forces assumed control of the governorate at that time, and they continue to exclude the Gol from Kirkuk city. ${ }^{8}$ However, since 2008 the Gol has gradually been reclaiming territory in more remote areas. This period of transition since 2003 has led to large demographic changes. Many Arab settlers pulled out of Kirkuk on the eve of the Ba'athist regime's collapse, but in some rural areas Arab communities have remained. Many Kurdish or Turkmen people returned to Kirkuk but were unable to reclaim their original dwellings; many were forced to erect temporary shelters or occupy other buildings, which led to a protracted process to rehouse and resettle communities. ${ }^{9}$ Today, issues of compensation and land ownership are still being contested. ${ }^{10}$ Across Kirkuk governorate different land areas have significant emotional resonances, such as those associated with the Anfal campaign against Kurdish civilians in 1986-89. Other areas are contested because they are of high strategic importance: for example, they may contain major oil installations, fertile agricultural land, water sources or major road links. However, underlying all this local complexity, different ethnicities and authorities need to find common ground to strengthen economic and water security. This is important because on-the-ground realities in Kirkuk are likely to outpace any top-down responses being planned in Baghdad.

\section{RAINFALL}

Iraq's climate is mainly of a continental, sub-tropical semi-arid type, with the north and north eastern mountain regions having a Mediterranean climate. ${ }^{11}$ Kirkuk governorate is located in the northern arid and semi-arid zones, with a Mediterranean climate (see Figure 2). This zone receives over $400 \mathrm{~mm}$ of rainfall annually (November to April), followed by a warm summer. Rainfall is seasonal and is followed by a distinctive dry period from June to September (Figure 3). Irrigation is practised, from springs, streams and boreholes, and major crops grown include wheat, barley, rice and chickpea. To the south are the steppes (grasslands), which receive 200$400 \mathrm{~mm}$ of rainfall in the winter months. ${ }^{12}$ This semi-arid zone is located between the Mediterranean and desert zones; summers here are extremely warm and winters cold. The steppes have limited irrigation, and crop production is limited to barley and wheat. Further south again, the desert zone is subject to low levels of rainfall ( $<200 \mathrm{~mm}$ per annum), with extreme summer temperatures. It extends from north of Baghdad to the borders of Saudi Arabia and Jordan. It is sparsely populated and irrigation is practised in isolated pockets. ${ }^{13}$ 
Figure 2: Climatic zones of Iraq

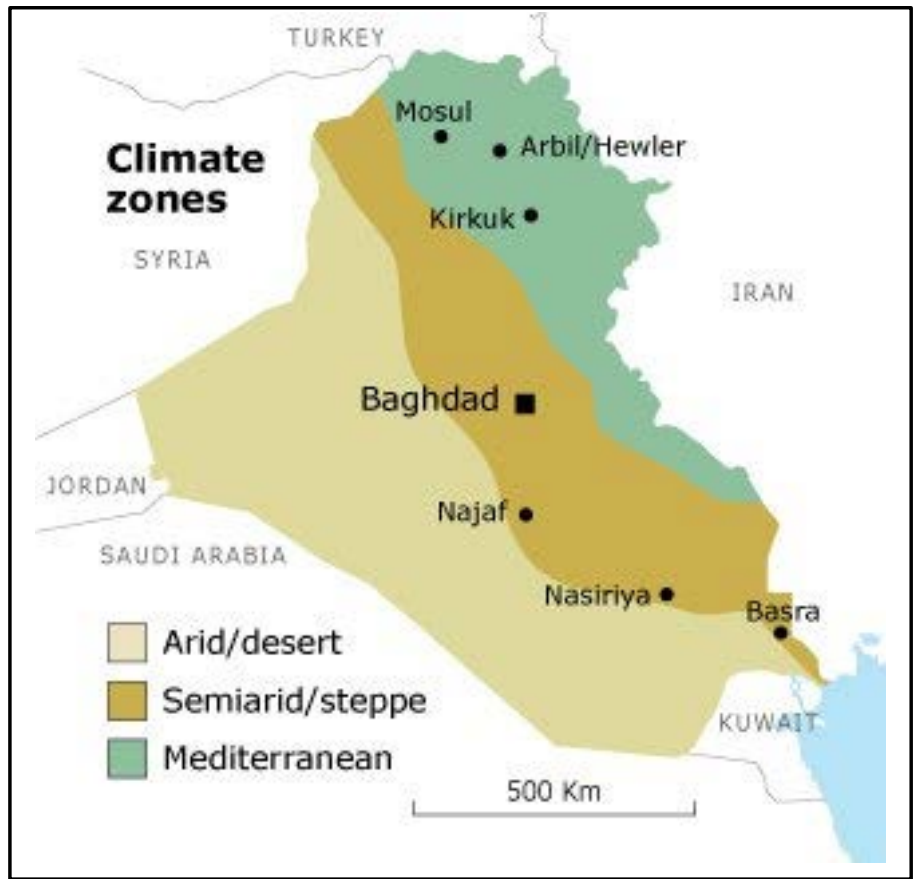

Source: N.A. Al-Ansari (2013). Management of Water Resources in Iraq: Perspectives and Prognosis.

Figure 3: Annual average rainfall in Iraq (1991-2015)

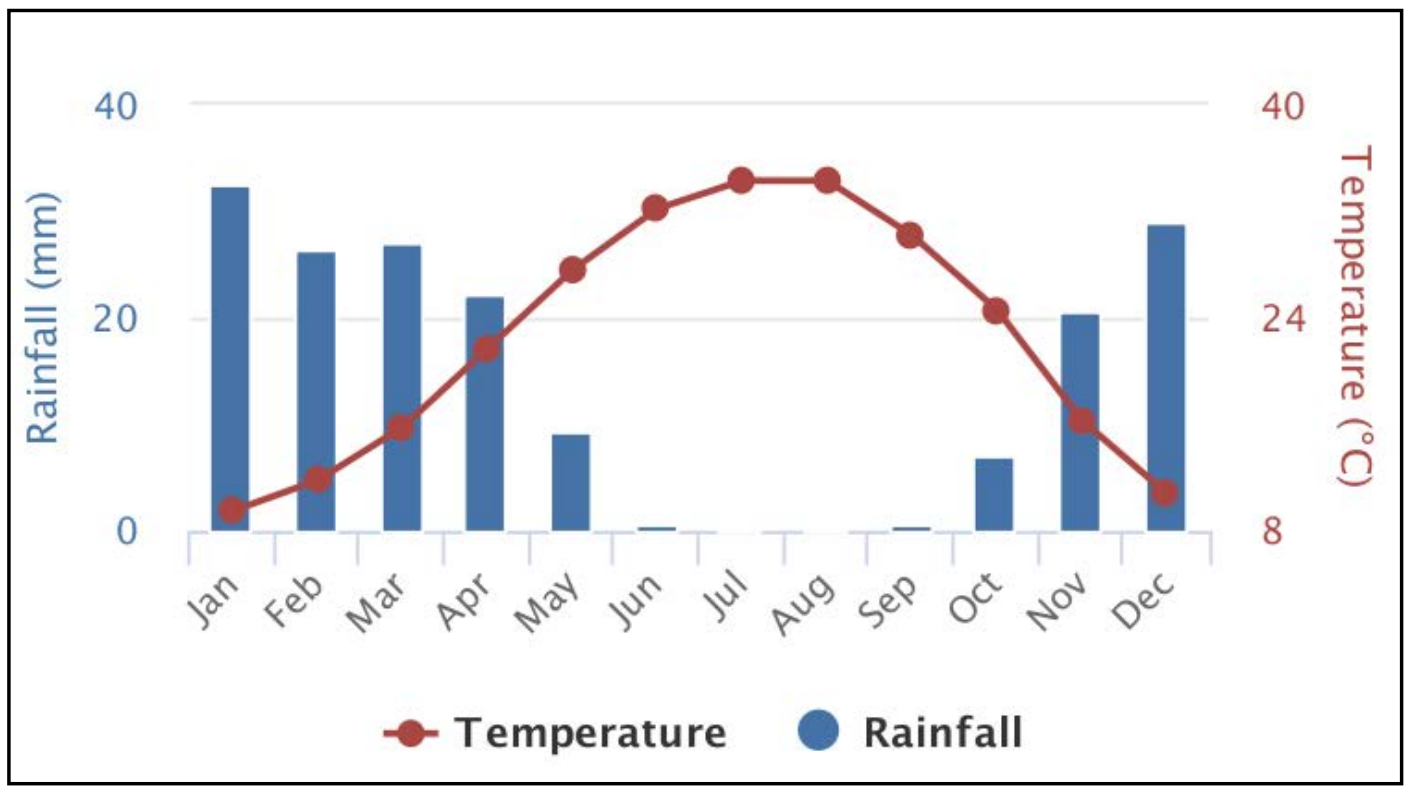

Source: World Bank Group. Climate Change Knowledge Portal. Iraq. Available at: http://sdwebx.worldbank.org/climateportal/index.cfm?page=country historical climate\&This Region=Africa\&ThisCcode=IRQ

\section{HYDROGEOLOGY}

Groundwater aquifers in Iraq can be divided into seven zones, ${ }^{14}$ as shown in Figure 4. Generally, these aquifers consist of extensive alluvial deposits of the Tigris and Euphrates rivers, and are composed of Mesopotamian-clastic and carbonate formations. ${ }^{15}$ The alluvial aquifers have limited potential because of poor water quality. The Mesopotamian-clastic aquifers in the northwestern foothills consist of Fars, Bakhtiari and alluvial sediments. The Fars formation is made up of anhydrite and gypsum inter-bedded with limestone and covers a large 
area of Iraq. The Bakhtiari and alluvial formations consist of a variety of material, including silt, sand, gravel, conglomerate and boulders, with a thickness of up to 6,000 metres. Water quality ranges from 300 to 1,000 parts per million (ppm). Another major aquifer system is contained in the carbonate layers of the Zagros Mountains. Two main aquifers are found in the limestone and dolomite layers, as well as in the Quaternary alluvium deposits. The limestone aquifer contributes large volumes of water through a number of springs. The alluvial aquifers contain large-volume reservoirs, and annual recharge is estimated at $620 \mathrm{M} \mathrm{m}^{3}$ from direct infiltration of rainfall and surface water run-off. ${ }^{16}$

Kirkuk is located in the Low Folded Zone (Figure 4), which extends across the northeastern region of Iraq. The aquifer consists of sedimentary formations and there is hydraulic continuity across the formation. Precipitation is the main form of groundwater recharge ${ }^{17}$ and groundwater movement is typically from north and northwest to south and southeast. Generally, the salinity of the groundwater increases from north to south, and increases from the recharge sources in the high land areas (less than 1,000 mg/l) towards the discharge areas along the Mesopotamia and Al-Jazira zones (more than $10,000 \mathrm{mg} / \mathrm{l}$ ). Groundwater quality is mainly bicarbonate at the recharge areas, and becomes sulphatic at the discharge areas. ${ }^{18}$

Good-quality subterranean water has been found in the foothills of the mountains in the northeast of the country and in the area on the right bank of the Euphrates. The aquifer in the northeast of Iraq has an estimated safe yield of between $10 \mathrm{~m}^{3} / \mathrm{sec}$ and $40 \mathrm{~m}^{3} / \mathrm{sec}$ at depths of 5-50 metres (Figure 5). Its salinity increases towards the southeast of the area until it reaches between 0.5 and $1 \mathrm{mg} / \mathrm{l}$. The aquifers on the right bank of the Euphrates, trapped between gypsum and dolomite at depths increasing towards the west, where water is found at 300 metres (at Abu-Aljeer), have an estimated safe yield of $13 \mathrm{~m}^{3} / \mathrm{sec}$. In the western part of that area the salinity of the water is only $0.3 \mathrm{mg} / \mathrm{l}$, compared with $0.5-1 \mathrm{mg} / \mathrm{l}$ in the eastern section. In other areas of the country good-quality water is fairly limited because of high levels of salinity. ${ }^{19}$ An estimated $0.08 \mathrm{~km}^{3} /$ year of water from the Umm er Radhuma aquifer enters Iraq from Saudi Arabia. Internal renewable water resources are estimated at $35.2 \mathrm{~km}^{3} / y e a{ }^{20}$ 
Figure 4: Hydrogeological zones across Iraq

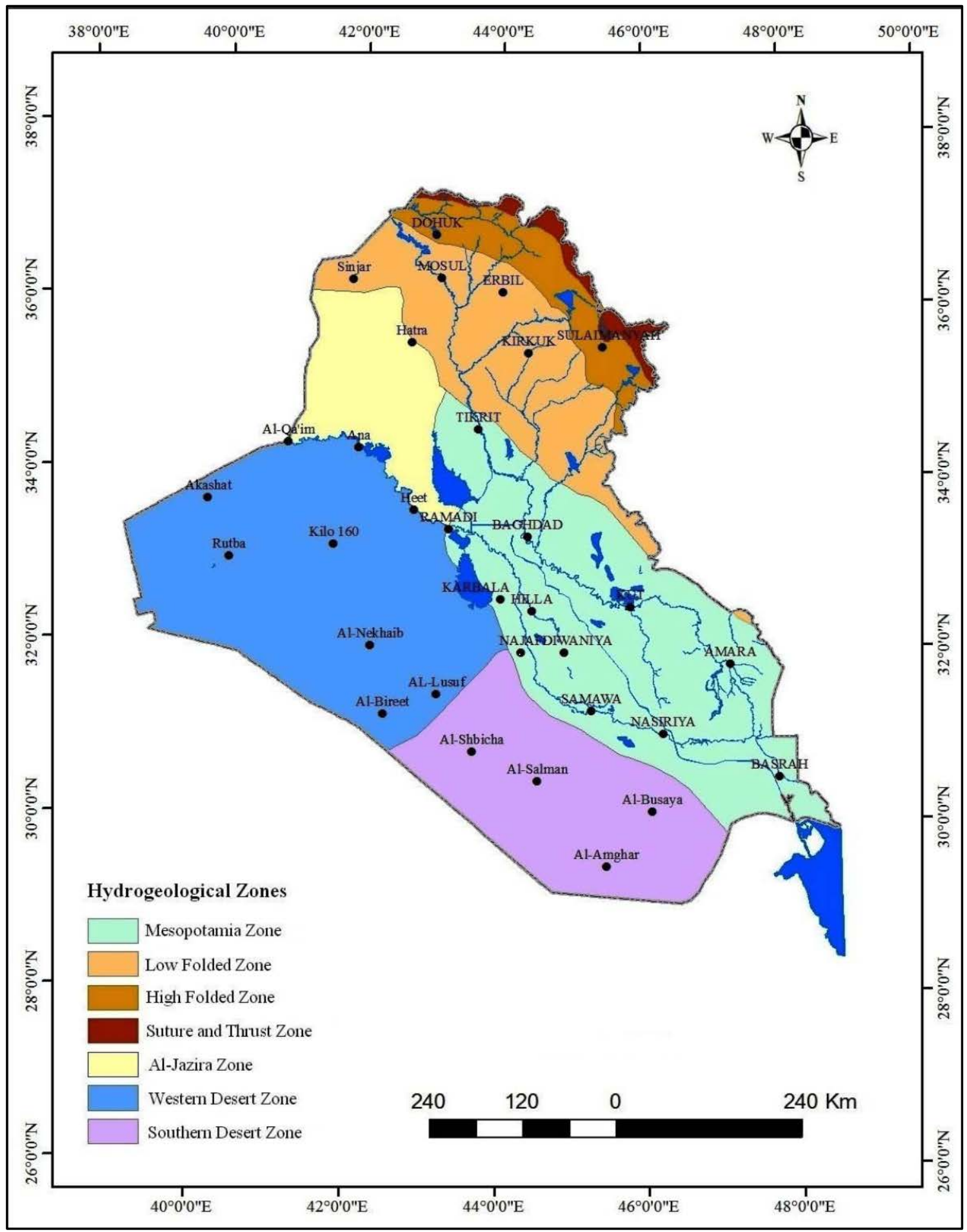

Source: H.K. Al-Jiburi and N.H. Al-Baswari. (2015). 
Figure 5: Mapped depth of water table

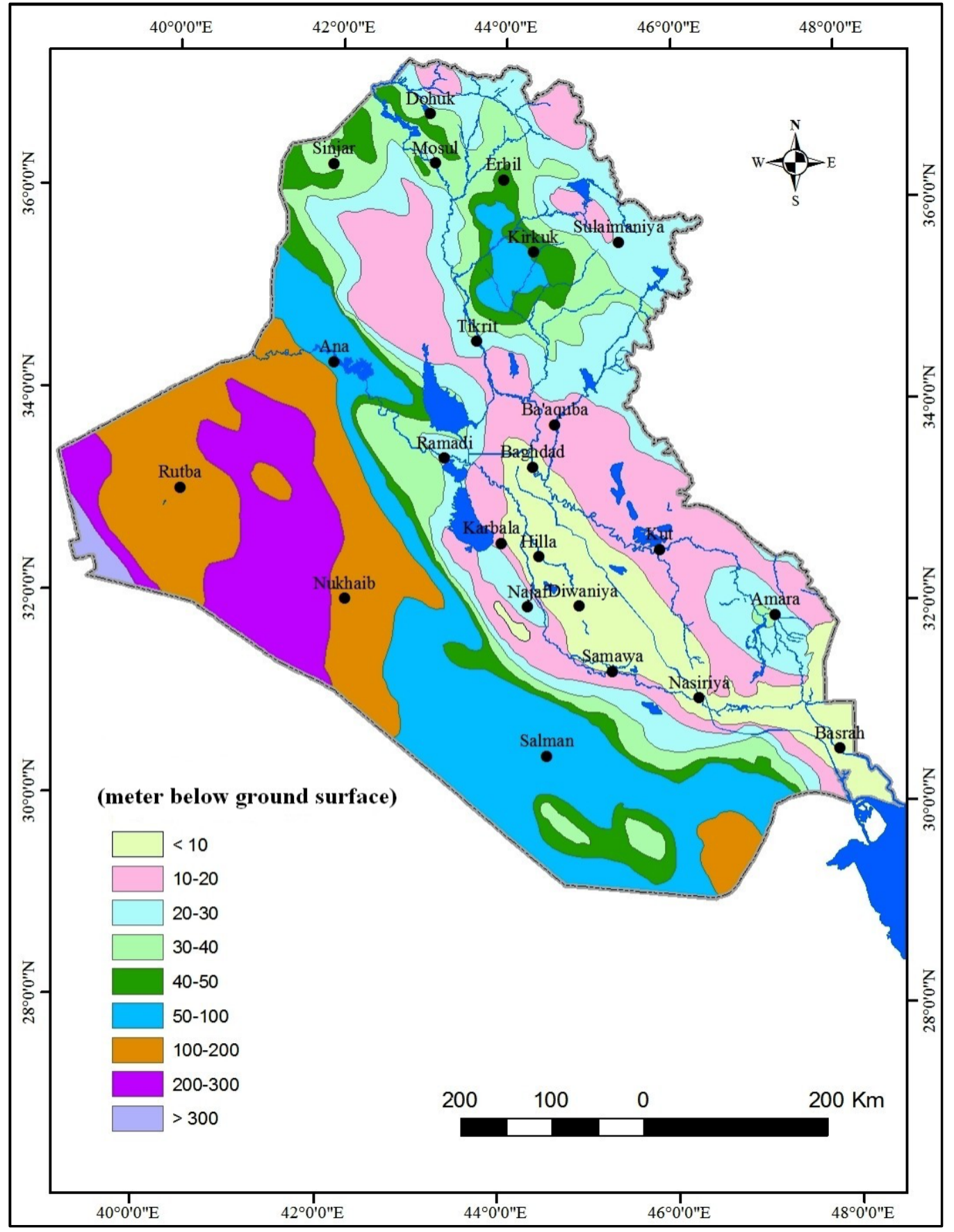

Source: H.K. Al-Jiburi and N.H. Al-Baswari. (2015). 


\section{SURFACE WATER}

Information for this section is taken from the Iraq country profile on the FAO AQUASTAT (2008) website, unless otherwise stated. ${ }^{21}$ Iraq has two major trans-boundary rivers, the Euphrates and the Tigris, both of which originate in Turkey (see Figure 6). Before their confluence, the Euphrates flows for about $1,000 \mathrm{~km}$ within the territory of Iraq and the Tigris for about 1,300km.

The area of the Tigris River Basin in Iraq is $253,000 \mathrm{~km}^{2}$, which is 54 percent of the country's total river basin area. The average annual run-off is estimated at $21.33 \mathrm{~km}^{3}$ as the Tigris enters the country. All the tributaries of the Tigris are on the river's left bank; from upstream to downstream, they are:

- the Greater Zab, which originates in Turkey. It generates $13.18 \mathrm{~km}^{3}$ at its confluence with the Tigris, and 62 percent of the total area of this river basin of $25,810 \mathrm{~km}^{2}$ is in Iraq;

- the Lesser Zab, which originates in the Islamic Republic of Iran and which is equipped with the Dokan Dam $\left(6.8 \mathrm{~km}^{3}\right.$ ). The river basin of $21,475 \mathrm{~km}^{2}$ (of which 74 percent is in Iraqi territory) generates about $7.17 \mathrm{~km}^{3}$, with $5.07 \mathrm{~km}^{3}$ of annual safe yield after construction of the Dokan Dam;

- the Al-Adhaim (or Nahr Al Uzaym), which drains about $13,000 \mathrm{~km}^{2}$ entirely in Iraq. It generates about $0.79 \mathrm{~km}^{3}$ at its confluence with the Tigris. It is an intermittent stream subject to flash floods;

- the Diyala, which originates in Iran and drains about $31,896 \mathrm{~km}^{2}, 75$ percent of which is in Iraqi territory. It is equipped with the Derbendi Khan Dam and generates about $5.74 \mathrm{~km}^{3}$ at its confluence with the Tigris;

- the Nahr at Tib, Dewarege (Doveyrich) and Shehabi rivers, which together drain more than $8,000 \mathrm{~km}^{2}$. They originate in Iranian territory and together bring about $1 \mathrm{~km}^{3}$ of highly saline water into the Tigris;

- the Karkheh, the main course of which is in Iran and which, from a drainage area of $46,000 \mathrm{~km}^{2}$, brings around $6.3 \mathrm{~km}^{3}$ yearly into Iraq - into the Hawr Al Hawiza during the flood season and into the River Tigris during the dry season.

The average annual flow of the Euphrates as it enters Iraq is estimated at $30 \mathrm{~km}^{3}$, with a fluctuating annual value of between $10 \mathrm{~km}^{3}$ and $40 \mathrm{~km}^{3}$. Unlike the Tigris, the Euphrates has no tributaries on its passage through Iraq. About $10 \mathrm{~km}^{3}$ per year are drained into the Hawr Al Harnmar (a marsh in the south of the country). The Shatt Al-Arab is the river formed by the confluence downstream of the Euphrates and the Tigris; it flows into the Gulf after a course of only $190 \mathrm{~km}$. The Karun River, originating in Iranian territory, has a mean annual flow of $24.7 \mathrm{~km}^{3}$ and flows into the Shatt Al-Arab, to which it brings a large amount of fresh water just before reaching the sea.

It is difficult to determine the average annual discharge of the Euphrates and Tigris rivers combined due to large yearly fluctuations. According to the records for 1938-80, there were years in the mid-1960s when $68 \mathrm{~km}^{3}$ were recorded in the two rivers and years in the mid-1970s when the amount reached over $84 \mathrm{~km}^{3}$. On the other hand, at the beginning of the 1960 s there was a critical drought year with less than $30 \mathrm{~km}^{3}$. Such variations in annual discharge make it difficult to develop an adequate water allocation plan for competing water demands from different sectors and to ensure the fair sharing of water among neighbouring countries. ${ }^{22}$ The Tigris, which originates in the Taurus Mountains of Turkey, travels along the northwest boundary of the governorate of Kirkuk. However, in recent decades the river's flow rate has reportedly declined by more than two-thirds. ${ }^{23}$ In Kirkuk, all five rivers and many seasonal watercourses (wadis) have reduced water flows due to climate trends, upstream use and increased demand.

Fluctuations in annual discharge have also caused large and sometimes disastrous floods as well as periodic severe droughts. The level of water in the Tigris can rise at a rate of over 
$30 \mathrm{~m}^{3} /$ hour. In the southern part of the country, immense areas are regularly inundated, levees often collapse, and villages and roads must be built on high embankments. For example, the Tharthar Reservoir was planned in the 1950s (along with other projects) to protect Baghdad from the ravages of periodic flooding on the Tigris by storing extra water upstream of the Samarra Barrage. ${ }^{24}$

The major part of river flows occurs during the spring flood period, which is from February through June on the Tigris and from March through July on the Euphrates. On the Tigris, the natural flow during this period makes up 60-80 percent of the total annual flow and on the Euphrates 45-80 percent. During the low water period (July-September), the natural flow does not exceed 10 percent of the annual amount under normal conditions.

Figure 6: Surface water resources in Iraq

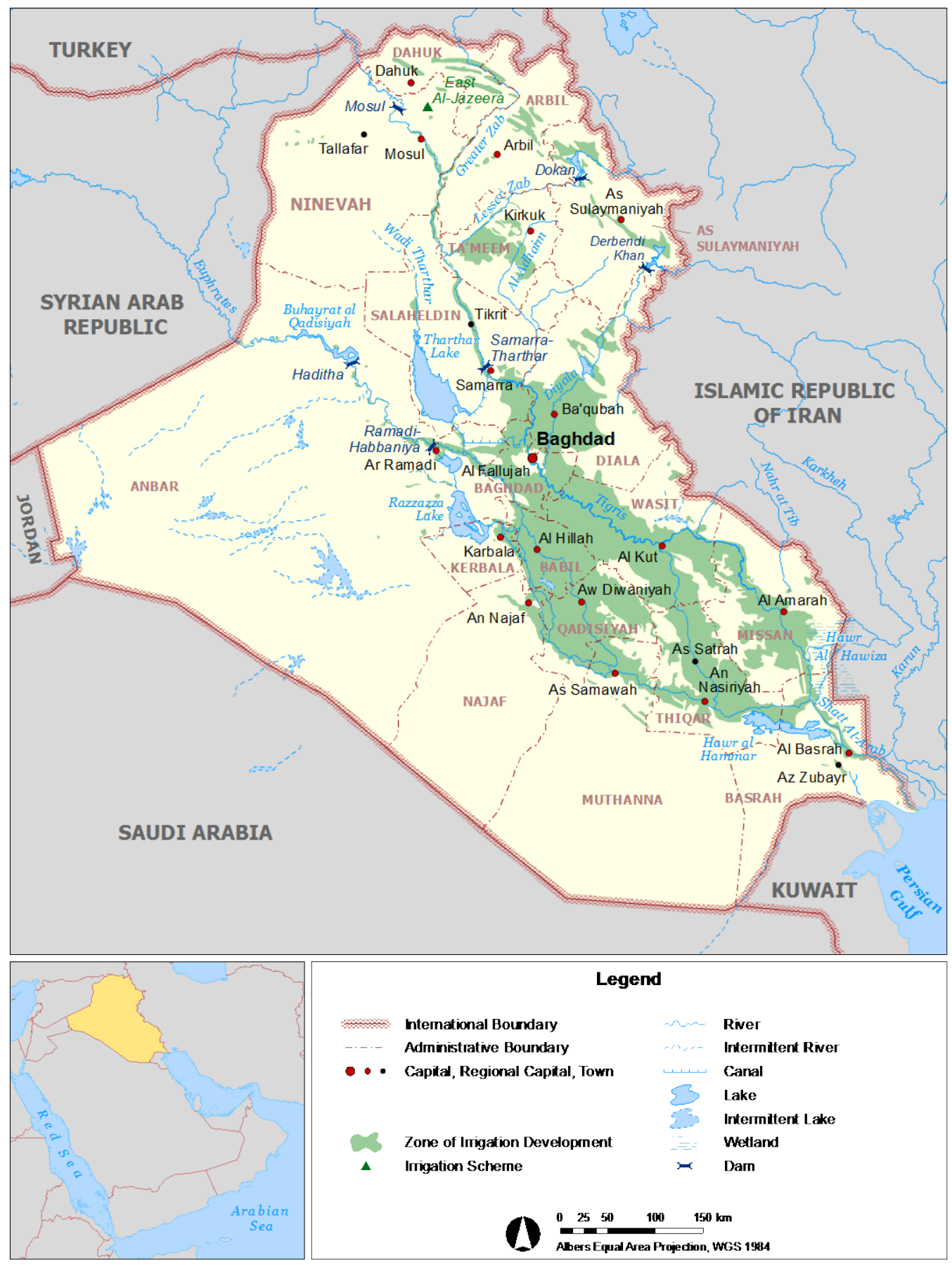

Source: FAO AQUASTAT. (2008). 


\section{WATER USE}

Unless otherwise stated, the source of information in this section is FAO AQUASTAT's Iraq country profile. ${ }^{25}$ In 2000, total water withdrawal in Iraq was estimated at $66 \mathrm{~km}^{3}$, of which 79 percent was for agricultural purposes, 6.5 percent for domestic supplies and 14.5 percent for industrial use. ${ }^{26}$ Hydroelectric power generation accounts for about 17 percent of current electrical energy production in Iraq. Existing power plants have been neglected for over a decade, however, and a number of new projects were suspended in the aftermath of the 2003 invasion. Irrigation potential is estimated at over 5.55m hectares, of which 63 percent are in the Tigris Basin, 35 percent in the Euphrates Basin and 2 percent in the Shatt Al-Arab Basin. Looking at Iraq's soil resources, an estimated $6 \mathrm{~m}$ hectares are classified as excellent, good or moderately suitable for flood irrigation. With the development of water storage facilities, the regulated flow has increased and has significantly changed the country's irrigation potential, which was estimated at only $4.25 \mathrm{~m}$ hectares in 1976. However, the development of irrigation depends to a large extent on the volume of water released by the countries upstream (Turkey and Syria).

The total managed water area in Iraq was estimated at 3.5m hectares in 1990, all of which was equipped for fully or partially controlled irrigation. The areas irrigated by surface water were estimated at 3,305,000 hectares, of which 105,000 hectares (3 percent) were in the Shatt AlArab River Basin, 2.2m hectares (67 percent) in the Tigris River Basin and $1 \mathrm{~m}$ hectares (30 percent) in the Euphrates River Basin. However, not all these areas are actually irrigated, since a large land area has been abandoned due to water logging and salinity. The areas irrigated from groundwater were estimated to total 220,000 hectares in 1990, with some 18,000 wells. Naturally, these figures need to be reviewed and updated in the near future. 


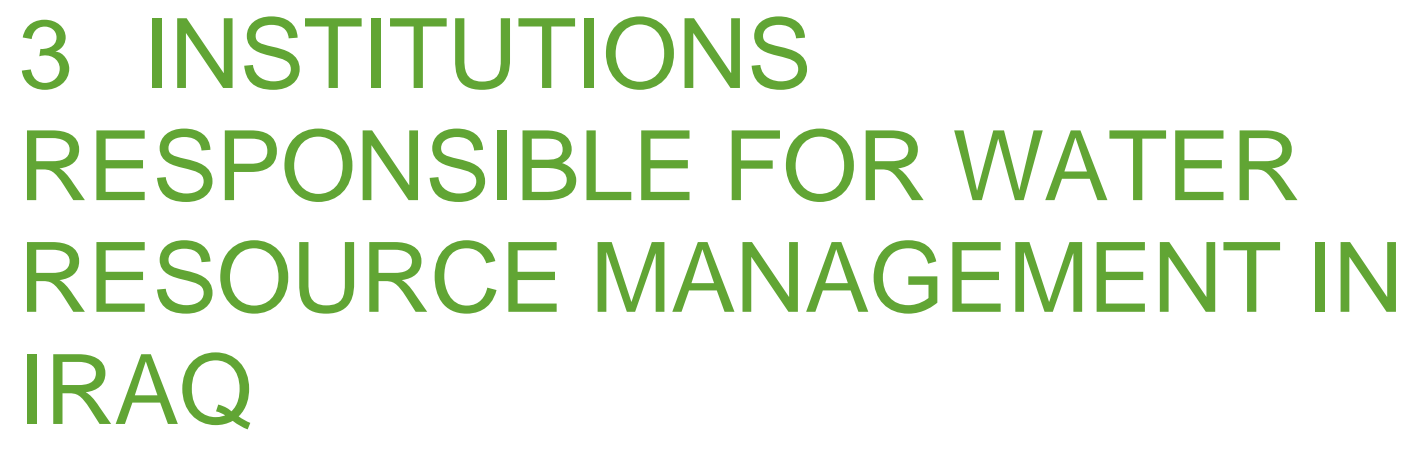

This section explores the role of institutions in water resource management. It provides an overview of the political dynamics that exist in Kirkuk governorate, before describing the roles and responsibilities of mandated institutions. It concludes by looking at how institutions could work together in a more effective manner.

\section{OVERVIEW}

In order to monitor and manage water resources effectively, all governments need sound institutions. In regard to water resource management, there are five essential duties to perform. The first concerns the ability to monitor (measure) water resources on a continuous basis. At the very least, all countries need representative monitoring networks for rainfall, river flow and groundwater levels, with water quality surveillance at key locations. Some of this important work can be undertaken at rural community level, while other aspects need the active involvement of competent local and national government institutions. The second requirement concerns the ability to allocate water resources to a wide range of water users in a fair and equitable manner. This requires institutions to assess water demands and to facilitate a bargaining process between different water users. The third requirement is to ensure that robust water laws and rules are applied, so that water sharing agreements are adhered to. Next, many institutions at various levels need to work together in a meaningful way. The principle of subsidiarity should be applied. This means that water and land resources should be managed at the lowest most appropriate level. Central-level authorities should really be working in support of local institutions and essentially performing only those tasks that cannot be undertaken at a 'lower' level. Fifth, mandated institutions must ensure that water infrastructure is 'fit for purpose' so that water resources can be stored, treated and distributed efficiently. The seriousness with which institutions address each of these important elements is an indicator of their commitment to ensure water security for their citizens.

In Kirkuk, the institutional arrangements for managing water resources are complicated. The region has seen a shift in demographics and the governorate's population now includes Kurds, Arabs, Turkmens and Assyrians, which means that allegiances are increasingly split between the KRG and the Gol. Historical political legacies and competing claims over who should govern Kirkuk inevitably affect funding and decision making at every level. This has led to underinvestment in the governorate's water infrastructure, with Gol funding focused largely on irrigation and agriculture. Since 2005, Kirkuk has officially come under the jurisdiction of the Gol; there is now an informal power-sharing arrangement between the two sides, but financial investment into the governorate remains limited. This has had adverse consequences for the KRG's relationship with Baghdad and negative outcomes for the people of Kirkuk.

Oxfam's research has identified some of the emerging problems. For example, a large percentage of citizens in Kirkuk are not satisfied with basic services, such as water supply, sanitation, agriculture related services and energy. Government institutions are considered inefficient and they lack human, material and financial capacity to manage water resources. Another concern is the centralized governance system, which is reflected in policy, laws and practice. Historically there has been an emphasis on control, while standards of basic services 
have been neglected. While the principle of subsidiarity is widely promoted in water resource management, in Iraq local institutions remain subservient to central authorities.

However, any criticism of government institutions needs to be seen in the context of the radical challenges that have beset Kirkuk. Institutions in Iraq have been affected by years of sanctions, dispersal of talent, destruction of traditional governance systems and corruption. Thus, when reviewing the capacity of ministries, departments and agencies (MDAs), it is important to balance criticisms with the pressures that central government has faced over many years. Ultimately, national and regional progress in water resource management requires clarity about the roles and responsibilities of a range of actors in central government and in Kirkuk governorate, the private sector and civil society. It is helpful to look at the current arrangements for managing water resources.

\section{WHO IS RESPONSIBLE FOR WATER RESOURCE MANAGEMENT IN IRAQ?}

Central government in Baghdad has the leadership responsibility in relation to setting policy and strategy for water resource management. The Ministry of Water Resources (formerly the Ministry of Irrigation) leads this work. It is responsible for safeguarding the country's water resources and operating the major dams, hydroelectric power stations and pumping stations that serve irrigated areas. It plays a broad role in the provision of water for both domestic and productive usage. It is understood that its immediate priorities are:

- safeguarding the quantity and quality of water resources so that they benefit people and the economy

- protecting Iraq from the risks of flooding and drought

- increasing internal resources and capacity, following years of conflict in Iraq, so that its receptive capacity is strengthened

- fostering links with all neighbouring regions and countries that are built on mutual trust and respect

- Implementing national strategic plans for water and land resources.

However, it is also common for a number of other government MDAs (such as agriculture, energy, environment and health) to have partial responsibility for managing water resources. This means that full clarity about roles and responsibilities is sometimes lacking. For example, the Ministry of Agriculture is responsible for managing land tenure, supporting farmers to irrigate land and distributing machinery and irrigation equipment. It also tries to ensure that farmers have access to markets.

There are areas where collaboration with central authorities is particularly important, and three in particular stand out. The first is the agricultural sector, which is the largest consumer of water. Irrigation techniques need modernizing to improve water use efficiency. The second is collaboration with local farmers and community-based institutions. Oxfam's research shows that erratic water supply and growing environmental problems are having a detrimental impact on farmers. Many are abandoning farming, and local water supply and sanitation systems are deteriorating. The third concerns wider environmental requirements and engagement with the Ministry of Environment. On the supply side, water abstractions are increasing but they are largely uncontrolled. There is too little water serving too many competing demands, and as a consequence basic environmental demands are frequently overlooked.

In addition to the Ministry of Water Resources, the Directorate of Water (DoW) is the frontline organization responsible for implementing government policy and strategy in Kirkuk. Its strength lies in its proximity to communities and households who need water supply services. It also works with groups in society, such as farmers' groups. However, a lack of resources often acts 
as a major constraint to implementation and to ensuring that water supply services keep functioning. Engagement with local water and agriculture directorates will help to ensure that real water management problems are being addressed.

Oxfam's research identifies that, since 2003, ethnic communities have been remarkably successful in negotiating disputes over land and water resources in the absence of government action. Historically and currently there has been cross-cultural intermingling, with individuals and communities living as neighbours, working side by side in a cooperative manner. Indeed, most people in host communities do not begrudge the help that is being given to displaced populations; however, they would also like help to address their own needs. Oxfam recognizes this as an opportunity to foster a closer working relationship between community-based institutions and local authorities. It is also an opportunity to look at longer-term water security planning requirements, in the knowledge that camps for internally displaced persons (IDPs) may become more permanent and that water usage requirements will evolve.

Agriculture accounts for the biggest proportion of Iraq's water usage, which means that farmers are central to the sustainable use of water. In the WASH sector, community water user associations are often responsible for managing water and sanitation services, and the community management model forms a central component of much WASH sector strategy and policy. The same approach should be extended to the management of water resources, particularly where farmers' groups or cooperatives are responsible for water abstraction and consumption. However, it is also important to realize that local institutions will require effective external support from responsible government authorities. This necessitates a strong emphasis on working with local institutions and fostering close links with key government authorities (such as the DoW and the Directorate of Sewerage (DoS)). 


\section{WHY IS WATER RESOURCE MANAGEMENT IN IRAQ IMPORTANT?}

This section looks in more detail at current water management problems in Kirkuk and the general issues arising. It is hoped that these insights will help point the way to strengthening practices of water resource management.

\section{BACKGROUND}

Iraq's recent history has been exceptionally turbulent, and one aspect has been a shift from an authoritarian system to one with a democratically elected government. This has led to a complicated situation whereby the country has acquired democracy but has struggled to establish rule of law and sound institutions for governance. Post-invasion violence is still widespread ${ }^{27}$ and the country is fragmented, which threatens to unravel any existing political and social relationships. Vital infrastructure, such as water supply, irrigation and energy systems, continues to be targeted and damaged or destroyed. Surface water and groundwater sources continue to be polluted - sometimes deliberately. In such a difficult working environment, economic development is massively constrained, which in turn leads to a gradual deterioration in the standards of basic services. When water supply services are disrupted, it creates major food security, sanitation and health crises. This is an issue of major concern to Oxfam and its development partners.

Iraq depends on the river flows of the Tigris and Euphrates, which originate from outside the country (Figure 6). This means that it must manage its relations with neighbouring countries to ensure that water management is equitable and fair. Without close collaboration with neighbouring countries and disputed territories, Iraq's water security will be threatened; ${ }^{28}$ thus it can have no complacency in the way it manages its water resources. To overcome these problems at a national level, the government must address the multi-pronged dilemma of establishing the rule of law and building democratic institutions while at the same time working hard to re-establish and improve basic services. This poses major challenges for decision makers, but it also requires NGOs working in Iraq to identify how best they can contribute in this difficult situation. The challenging nature of water management in Kirkuk is explored below.

\section{PRESSURES ON WATER RESOURCES}

There are many growing pressures on water resources in Kirkuk, including population growth and increased water demands for agricultural and industrial uses. ${ }^{29}$ Changes in land use, climate variability and climate change also feature. There are also strategic problems that make policy and strategy planning difficult. As described in section 3, Kirkuk is a disputed territory, which means that different sides are targeting control of its water sources and installations. One of the main problems is a lack of coordination in the way that water resources are used and allocated. Against this backdrop water insecurity, displacement and humanitarian needs are likely to feature in the short to medium terms. In many ways, Kirkuk governorate represents a microcosm of Iraq's water security challenges, and many of the water resource management issues it faces are part of a bigger environmental and socio-economic picture (see Figure 7). 
Figure 7: Water dimensions in fragile states

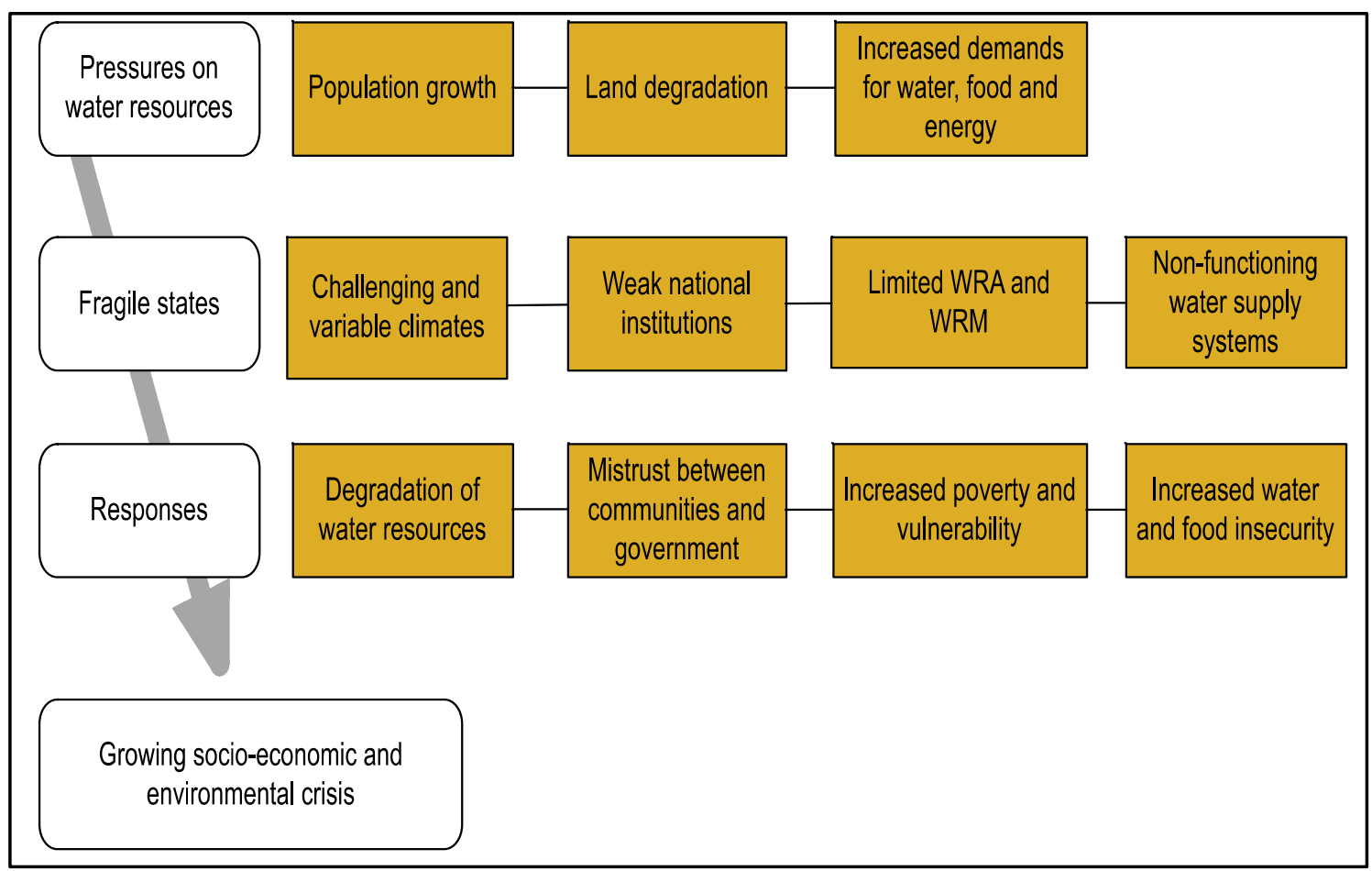

In Kirkuk there are three main pressures: growing water demands for agriculture and industry; increased population caused by internal human displacement; and a gradual decline in basic infrastructure. These are each discussed in turn below.

\section{WATER DEMANDS FOR AGRICULTURAL AND INDUSTRIAL USES}

Agriculture is a major consumer of water. In Kirkuk governorate 15 percent of the working population is employed in agriculture and fisheries. Since 2005 many fish farms have been established in Laylan district, while an area of approximately 142,000 hectares across the governorate is used for irrigated agriculture. The customary practice in Iraq is to flood irrigate ${ }^{30}$ summer and winter crops. In some localities (such as Daquq), farmers work with local water authorities to determine when irrigation can begin and how water should be allocated. This is based on a sequential system, often referred to as contiguity. However, in other areas (such as Hawija) formal systems do not exist and farmers often decide the irrigation schedule themselves. Farmers reliant on groundwater sources for irrigation (like those in Sharinja Bulak and Schwan) are also more autonomous in the methods they use to irrigate their land. This is not necessarily bad, but customary water management arrangements may be overlooked if they are not part of formal water allocation and irrigation policy. Oxfam's research has identified that farmers already play an important role in the management of local water resources; they often have a deep knowledge of the environment in which they live and work and they also have knowledge of emerging environmental risks. Yet farmers may also need support to establish successful community irrigation systems, otherwise significant volumes of water may be wasted. This concern is reflected in a comment made by a farmer in Sharinja Bulak, interviewed in 2016:

I do not know the amount of water we use to irrigate. I run the pump continuously for three days [to] cover 300 dunams. ${ }^{31}$ I run the pump three to nine days a month, especially during July through to September.' 
The importance of industry to Iraq is incalculable. Extensive efforts have been made to build up the oil industry in Kirkuk, which now employs one percent of Iraqis, ${ }^{32}$ while around 35 percent of the governorate's total employable workforce are engaged in the mining and manufacturing sectors and 14 percent are employed in construction. Reconstruction and modernization are vital for the country's future, but industry consumes large volumes of water and also discharges wastewater to the environment. Without sound stewardship of water resources, these industries have the potential to increase water scarcity if they are not made part of a wider regional and national water security strategy.

In Iraq the preoccupation with oil production often overrides environmental concerns, and the right to sign contracts with international oil companies is a contentious issue in disputed territories like Kirkuk. This can have a destabilising effect. The oil industry uses large amount of water as a tool for exploration, uplift and injection. For every barrel of oil extracted, about two barrels of water are injected into the oil reservoir to maintain pressure. This water is pumped (free of charge) from the Lesser Zab, filtered and deoxygenated before being injected by highpowered pumps into 22 injection wells. This water is then used by the North Oil Company (NOC) or supplied to other oil operators. Once injected, the water is unusable for other purposes, as heat and pressure make it up to four times more saline than seawater. While water injection is considered cheap and efficient, extreme over-pumping in the 1980s and 1990s caused damaging intrusions of water and a rise in oil/water contact, leading to a decline in the quality of crude oil and the closure of some oil wells, which led to new wells being drilled. Oil revenue is extremely important for Iraq's future, but efforts must be made to make oil production more palatable and less harmful to the environment.

Oxfam's research shows that water usage in Kirkuk is fragmented. Different water uses and users (such as agriculture, fisheries, mining, oil, industry and energy) pursue different management approaches and compete with domestic users. Against this backdrop, both urban and rural communities express concerns about water quantity and quality. They believe that they can no longer take their historical water sources for granted. One of the clearest examples of growing tension involves farmers who flood irrigate using water from the Kirkuk Irrigation Project and who have been affected by the timing of discharges from the Dukan Dam. The dam operators are primarily concerned with maximizing energy production for the Kurdistan region and ensuring dam safety. However, if downstream discharges are uncontrolled or inadequate, this can lead to flooding and engender a sense of mistrust between upstream and downstream communities. This creates local water disputes, which sometimes reach breaking point:

'An argument breaks out [between upstream and downstream users]. Sometimes they fight with sticks. Sometimes knives. Sometimes guns. The community helps to resolve the dispute. The people come and sit together. Sometimes a mukhtar ${ }^{33}$ or sheikhs get involved. Sometimes the mukhtar or community member takes the disputing parties to the police, not to be charged, but so the police can help solve the problem.'

Local NGO, Daquq, 2016

Local tensions over water are a major concern, though Oxfam's research also shows that communities often have their own informal mechanisms for dispute resolution. Disputes between farmers and energy producers often come down to defining water requirements and options for sharing and managing water resources based on availability. These customary water management practices should be strengthened. Without adequate monitoring and management arrangements, farmers will continue to leave the land because of insufficient water, unmaintained irrigation infrastructure and unresolved land claims. 
In 2013 the Office of the UN High Commissioner for Refugees (UNHCR) estimated that there were 1.2 million internally displaced persons (IDPs) in Iraq. Recent estimates suggest that this has increased to more than 3 million. ${ }^{34}$ Large-scale human displacement in Kirkuk has resulted in the formation of camps and informal settlements for displaced people. These camps impose significant demands on local water resources and require water resource assessments to be undertaken. This knowledge has major implications for international organizations and government agencies that may be tasked with establishing and sustaining emergency water supply systems. In such circumstances, a fundamental requirement is to assess medium- and long-term water demand, ensuring the delivery of safe and adequate water supplies in accordance with the Sphere minimum standards. ${ }^{35}$

To make sense of the potential demand on water resources, it is helpful to take a closer look at population densities. An article published in the journal Waterlines notes that a densely populated IDP camp, designed to Sphere minimum standards, can result in a population density in excess of 22,000 people per $\mathrm{km}^{2}{ }^{36}$ Assuming that each person receives 15 litres of water per day, the recommended minimum in the Sphere guidelines, this implies a daily water demand of $330 \mathrm{~m}^{3}$ per day per $\mathrm{km}^{2}$. Annually, this amounts to $120,450 \mathrm{~m}^{3}$ per $\mathrm{km}^{2}$. This volume of water equates more to the level of demand of a city than a rural settlement and highlights that the availability of water resources should not be taken for granted. Some of the problems encountered in supplying IDP communities are discussed in Box 1.

\section{Box 1: Urban water supply in Kirkuk}

On the northern outskirts of Kirkuk city, 15,000 Kurds and Christians live in the suburbs of Seykanian, Shoraw and Googachel. Since 2014, these suburbs have hosted 2,000 IDPs who rent houses, although by March 2016 only 40 families remained. For domestic water supplies, everyone relies on 10 groundwater wells that were donated with the land after 2003. People generally have access to water for four hours every two days. In the summer of 2015 access was for four hours every three days, with some households receiving no water for two weeks. People protested on the highway into Kirkuk, demanding that the governor do something about their water supply; the governor asked the DoW to find a solution. Meanwhile, a member of the community asked a local NGO to negotiate with the DoW. The outcome was the installation of 1,500 metres of pipe to connect some houses to the public system of Arafa, a suburb built by the British for the oil industry workforce. For their unmetered groundwater from the Upper Bakhtiari formation, people pay the DoW IQD 3,000-5,000 (approximately $\$ 2.40-\$ 4.00$ ) a month.

\section{PHYSICAL INFRASTRUCTURE}

Large parts of Iraq's water supply, sanitation, agriculture and energy infrastructure have been damaged or destroyed in recent years. Infrastructure has also suffered from years of underinvestment and inadequate operation and maintenance. In 2012 it was estimated that approximately 88 percent of households in Kirkuk governorate had access to an improved water supply. Of this total, 70 percent of households were connected to a public water supply network, with 10 percent reliant on access to an improved well or spring source. Approximately 8 percent of households were reliant on unprotected surface water sources (such as streams or rivers) for their water supply. However, for those connected to a pipe-borne water supply, standards of service varied considerably. It is estimated that only 7 percent of households received a continuous uninterrupted supply, while at the other end of the scale approximately 6 per cent of 
households received water for less than one hour each day. The vast majority of households received water for between two and 10 hours daily.

Households interviewed by Oxfam in 2016 reported that standards of water supply had declined since 2012. An estimated 64 per cent of households surveyed stated that the water supply network was in need of repair, while 42 per cent raised concerns about water quality. Typhoid, diarrhoea, scabies and other water-washed diseases are emerging as health problems of major concern. Access to adequate quantities of water is also a cause for distress, with households experiencing water shortages in the dry season months. The reasons for this are complex but include increased water demands for agriculture and industry as well as a growing population. Routine operation and maintenance of water supply services have been constrained by inadequate investment. Sums of money are spent on rebuilding water supply facilities and subsidizing water costs, but high consumption and wastage of water, a lack of water metering and inadequate tariffs mean that routine operation and maintenance are often lacking. This has led to deteriorating water supply services. Historical management records also lack detail to enable an assessment of water usage patterns and the continued state of water resources. This is a consequence of Iraq's turbulent history and reflects a general weakening of state capacity.

A decline in water supply services has also affected sanitation facilities. Only 16 percent of households in Kirkuk are connected to the public sewerage system. The vast majority of households are reliant on cesspits, which reportedly are emptied every 4-6 months. Despite the presence of a centralized sewage treatment facility (constructed in 2010), sanitation services are still limited in scale; this suggests that not all components in the sanitation system (containment - removal - transportation - treatment - disposal or reuse) are being addressed. In Kirkuk, Oxfam's research shows that the focus has been primarily on technology and the construction of latrines. This is understandable given the difficult working environment, but other aspects of the sanitation system also need to be addressed.

\section{Box 2: Rural water supply - a case study}

Around 25,000 people live in the sub-district of Schwan, in Schwan town and in 75 villages. The sub-district relies on good-quality groundwater from the Upper Bakhtiari formation, except for some villages that rely on river water. According to the DoW office director in the sub-district, each well drilled by the Schwan water authority costs IQD $120 \mathrm{~m}$ (approximately $\$ 96,000$ ), including the pump, but the number of wells is proving inadequate for the 800 families living in the town. Townspeople receive two hours of water every second day, while those living on hilltops receive just half an hour of water every second day. There is a timetable for this. Since 2015, townspeople pay the DoW IQD 6,000 (approximately $\$ 4.80$ ) every two months for their unmetered water. Villagers do not pay for unmetered water, but in summer many wells run dry and people must truck in water or use a neighbour's personal well. Villagers also have to go through a bureaucratic procedure each month to obtain subsidized fuel to run the submersible pump needed for each well. First, they must get a letter from the director of the sub-district water authority and take it to the DoW in Kirkuk city, where they pay for a month's worth of fuel, based on running a pump 2-3 hours a day. The DoW provides the villager with a paper to say that they have the right to collect the specified amount of fuel from the government supplier, the Directorate of Petroleum Products. The villager must organize fuel transport and storage. Before 2014, fuel trucks delivered fuel to each village but this service has stopped because there is no fuel to run government vehicles. Kirkuk has experienced fuel shortages since 2015 due to road closures on routes to Baghdad, and local authorities have received no budget to purchase fuel since the beginning of 2014 .

Source: Focus group discussions carried out by Oxfam in Schwan town, Schwan sub-district. Participants were local community members, council members, and water authority engineers from the sub-district. 
The development and expansion of sanitation facilities in Kirkuk has had a mixed impact. This is because large-scale infrastructure projects have often been constructed without sustainable operating models; this makes local people sceptical of large infrastructure projects that fail to deliver the expected outcomes. NGOs may not be involved in delivering all the components of the sanitation system, but they should work with municipalities and local authorities to ensure that the entire system is functional. In the absence of safe collection and disposal methods, the risk of environmental contamination is real.

The natural environment has been a major casualty of the crisis in Iraq, and the once biodiverse ecology of Kirkuk has been devastated over the past 50 years. Upstream dams and water diversions have affected the once forested plains and hills north of Kirkuk city; these are now a desert in summer, creating frequent dust storms. During the international trade embargo, people cut down trees for heating and cooking. Land clearance, livestock grazing and unsustainable water usage practices also went unchecked. Post-invasion, point and diffuse water pollution, failing sewerage systems and growing amounts of solid waste have all contaminated the environment. Uncontrolled development (such as road construction, quarrying and oil drilling) and continuing conflict are also affecting the environment and ecology. Due to the protracted nature of the crisis, industry is not required to follow any environmental standards. Oil refineries have created a 'valley of oil' in the Al Multaqa area, west of Kirkuk, where untreated waste runs in black rivers across the land. Around Altun Kupri, factories release untreated waste that contaminates surface and groundwater sources. The oil industry is not required to conduct conservation or rehabilitation work and there is no regulation of environmental enforcement. To its credit, the DoW is aware of the issues and intends to phase in regulations; however, both the DoW and the Directorate of the Environment in Kirkuk lack adequate capacity (in terms of human, financial and material resources) to enforce environmental laws. It is projected that water availability in Iraq will diminish in the coming years at both national and regional levels. This might even be to the extent that minimum environmental flows will not be achieved in some regions. Over-abstraction may also lead to increased salinity in soils. As the population grows and the economy matures, these pressures will only increase.

Considering the sheer magnitude of the problems identified, it is clear that action on water security planning is urgently required. However, there needs to be common agreement on what problems should be addressed and the transitions to be undertaken. Oxfam's research has identified four key issues as having a significant potential impact on water security in Kirkuk:

- Kirkuk's water resources are coming under growing pressure. If this goes unchecked, it has the potential to deepen divisions between different ethno-sectarian groups.

- Iraq embarked on a political transition some 10 years ago. However, a lack of financial investment and weak institutions underlie many of the frustrations in Kirkuk today. The issue of how top-down water resource management approaches will be applied in Kirkuk remains unresolved.

- NGOs like Oxfam carry out WASH service delivery on a relatively limited scale, but their involvement in water resource management is important. First, it is a direct benefit to the communities and households served. Second, if organizations undertake innovative water resource management work, it will assist larger service providers like the KRG and the Gol to deliver services at scale.

- Lastly, community-based institutions in Kirkuk have already demonstrated willingness and demand to engage in monitoring and managing water resources. Many groups have their own informal arrangements for managing water resources. However, they have also expressed a concern that they cannot just sit and wait for external solutions that are not forthcoming. 


\section{MOVING FROM IDEAS TO ACTION}

This section aims to fill a gap by identifying areas where water security planning approaches can take place. It recognizes that progress may be quicker at local level involving local institutions. However, it would be short-sighted to ignore wider water management approaches, and where possible local-level initiatives should complement national water and land strategies.

It is very hard to predict the future. The thinking, therefore, is that the WASH sector in Kirkuk should focus on three important issues over which it has some control. The first priority for INGOs is to review their own standards of WASH service delivery. Two important inter-related environmental aspects need consideration: the first is the security of water resources in WASH programmes, and the second is the way that sanitation is conceptualized. This means that water supply systems should be assessed to make sure that they are not deteriorating in terms of water quantity and quality. Assessments should also be undertaken to make sure that sanitation and wastewater facilities are not polluting the environment. A key underlying issue here is changes in population density and the impact of IDP camps on local water resources. The second priority is to work with local institutions (such as farmers' groups) to solve real water management problems. To do this, INGOs should contribute to the generation of hydrometric data. Designers of field programmes will need to think about components of the water cycle rainfall, direct run-off, infiltration, groundwater recovery and surface water flows. A deeper understanding of water resources is required if the WASH sector is to help ensure that water availability is consistent with demand; currently, it seems that few data exist to accurately assess how water resources are being allocated. Furthermore, abstraction of both groundwater and surface water often goes unchecked. The third priority is to make sure that other organizations (such as MDAs) engaged in water resource management are working towards the same goals and 'scratching the right itch'. By this we mean it is important to address the most pressing water management problems, rather than those over which they have limited control. For example, the key issue may well be to understand how much water is available year-round and how it can be allocated more equitably and efficiently, particularly in the dry season months.

Oxfam's aim is to work with other INGOs to help establish basic water management practices in Kirkuk. To do this, a number of basic transitions are required so that water management can be improved. The first transition is to focus on strengthening standards of service delivery; this is all about ensuring that WASH services function year-round. Are water points climate-proofed so that they do not dry up in the summer months? ${ }^{37}$ Are multiple-use water systems or sources (MUS) in use to maximize the use of wastewater for small-scale gardens and livestock? Do sanitation and solid waste facilities minimize the risk of groundwater and surface water contamination?

The second transition is to strengthen knowledge and understanding. Stakeholders in Kirkuk will not be able to manage water resources if they do not measure them. If stakeholders do not know the relationship between rainfall, groundwater levels and surface water levels and flows, then evidence for changes in water availability will remain anecdotal. It is relatively simple to establish local hydrometric monitoring. The emphasis should be on collecting data to improve decision making and to focus on solving real water management problems, alongside local institutions. At the same time, practitioners must ensure that equipment and data collection methods are acceptable to government. Instrumentation needs to be accurate, so that it can contribute to the establishment of a national monitoring network and data repository.

The third transition is to explore areas where different water users are willing to collaborate. Establishing effective systems for assessing water availability, allocating water equitably, applying water laws, establishing robust institutions and rehabilitating water supply 
infrastructure will take considerable time. Thus, it makes sense to work with local institutions and focus on the most pressing problems.

The fourth transition involves ensuring that community-based institutions are not isolated. Many water management problems will be beyond the capacity of local institutions, and external assistance from government agencies will be required. The dividing line between community responsibilities and those of external support organizations will be context-specific. Oxfam is keen to work with both communities and other organizations to help define roles and responsibilities.

The fifth transition concerns the sustainability of service delivery. There is a preoccupation with building new water supply infrastructure in Kirkuk, but alternative measures need to be put in place to ensure that support is provided to communities post-construction. Similarly, efforts need to be made to address all elements of the sanitation system. Key to this is whether households and communities have the willingness and the ability to pay for services. This may be difficult to gauge, but ultimately funds must be put aside to keep services functioning. Oxfam's advocacy and influencing work should draw attention to recurrent operating costs. 


\section{OPPORTUNITIES ASSOCIATED WITH WATER MANAGEMENT IN IRAQ}

This section sets out a number of opportunities for the WASH sector and government counterparts to advance the goal of better water security planning in Kirkuk.

The first opportunity relates to the national Strategy for Water and Land Resources in Iraq (SWLRI), completed by the Ministry of Water Resources in 2014. This strategy was developed following a period of intense research involving national and international consultants. The SWLRI sets out an ambitious approach to reforming the country's water resources sector and addressing the risk of water decline. The strategy is all-inclusive and cuts across water, agriculture, energy and environmental sectors, but implementing it in such a challenging working environment will not be easy: it will require large sums of money and meaningful collaboration across multiple institutions, and it will need to be implemented in a transitional manner over many years. However, it is hoped that the recommendations set out in this report will contribute to managing water locally and will help to establish building blocks for wider water management. This should contribute to igniting interest in water security, and should also ensure that citizens do not just sit and wait for ambitious plans to be implemented.

Alongside this initiative, UNESCO and the Swiss Agency for Development and Cooperation (SDC) have begun a project to collect scientific data and to build institutional capacity. A localized approach to water management will complement this project; it will also help to demonstrate the role of citizen science in water resource management. ${ }^{38}$ Oxfam's strength lies in its proximity to local communities, which means that the likelihood of scientific data being collected, validated, analysed and applied should be greater. A common problem in water resource assessments is that data are collected but are not subsequently published or shared with local-level decision makers (such as farmers).

Managing water locally will also provide an opportunity to generate learning that can be applied elsewhere in the Middle East. It will help to strengthen local institutions by building the capacity of government technicians to carry out water resource assessments. This will help to build local resilience to climate extremes. Given the ongoing problems across the Middle East region, approaches to water resource management will need to be flexible and responsive. Thus, it makes sense for Oxfam to look at how water security planning can be applied in fragile and conflict-affected states (FCAS). It also makes sense for Oxfam to pursue a dual approach of a) practical implementation within its own WASH programmes and b) wider advocacy campaigns. Strategies should focus on solving real water security problems while at the same time contributing to tackling wider environmental problems. In the beginning, it also makes sense to focus on less contentious issues when working with different stakeholders. The initial aim should be to build mutual respect and trust. 


\section{CONCLUSIONS AND NEXT STEPS}

This report has identified that water resource management is a pressing problem in Kirkuk governorate, and it has also highlighted the fact that any follow-up action will need to be implemented in a difficult context. It is conceivable that there will be an escalation of violence across Iraq even after ISIS is defeated. It is also possible that relations between other ethnosectarian groups could deteriorate. An ongoing decline in standards of basic services may also lead to civil unrest. Thus, a key conclusion is that water security planning should be undertaken in a flexible and adaptive manner. A focus on managing water locally is considered to be a pragmatic approach and can be implemented alongside wider government-led initiatives.

The Gol and the KRG will both have strategic decisions to make on water security planning. Key to this is the requirement to forge a closer alliance between the two so that their approaches to water management are compatible. The common aspiration of wider water management approaches must be to ensure water security for all, regardless of ethno-sectarian divides. What needs to be done to develop these ideas across Kirkuk governorate? There are five main priorities at national level.

- First, a number of structural and institutional reforms must be pursued across the water sector. This will help to lay the foundation for implementing Iraq's wider strategy for land and water resources (the SWLRI). A priority is to establish an inter-ministerial framework, which should then look to clarify roles between different MDAs. It must also clarify constitutional arrangements between Baghdad, governorates and regions.

- Second, the KRG and the Gol must work together to resolve land claim issues in Kirkuk in an inclusive and fair manner. Land tenure regulation and zoning laws will help to prevent ad hoc urbanization. They will also help farmers to qualify for government subsidies and to access new farming technologies.

- Third, the KRG and the Gol should explore opportunities to create responsible and inclusive public-private partnerships so that major water supply, sewerage and agriculture infrastructure projects that contribute to national development plans are completed in a timely manner. National duty bearers should ensure that these are managed and implemented in ways consistent with international aid effectiveness principles. This recommendation reflects the difficulties in securing public funding.

- Next, the KRG and the Gol should establish robust policies and methods of regulation so that routine monitoring and compliance are undertaken. This is a pressing requirement for industrial waste, medical waste, sewerage, landfill sites and fossil fuel combustion, in addition to land and water resources.

- Fifth, a national hydrological monitoring network should be established in a phased manner. This will help to ensure that monitoring data are collected, validated, analysed and published, so that they benefit decision makers and local institutions.

There are also more immediate actions that can be pursued by the WASH sector. Over time it will be difficult for INGOs to advocate for change if they themselves are not directly involved in monitoring and managing water resources. Eight main priorities for the WASH sector are highlighted here:

- Engage with the Ministry of Water Resources to better understand its short- and medium-term water security priorities. Show a willingness to engage in water resource management activities and a desire to work with local institutions. 
- Monitor rainfall using simple, low-cost rain gauges and voluntary observers. This should be encouraged across Kirkuk, and local institutions that declare an interest should be involved.

- Conduct hydrogeological studies at a small number of locations. This should be combined with monitoring of rainfall. The development of localized monitoring programmes should be developed in partnership with local government, which will need to provide external support to local institutions.

- Monitor surface water flows at a small number of springs and streams, which will contribute to national monitoring programmes. It is of particular importance to understand dry season flows.

- Review current WASH programmes to identify how measures can be put in place to climate-proof water sources and establish multiple-use water system (MUS).

- Review sanitation and solid waste facilities to identify how contamination of water and land resources can be prevented.

- Document evidence of customary water management practices in Kirkuk governorate. This study has identified that some community institutions already have informal arrangements (operating principles) for managing water resources.

- Build consensus across development partners and academic institutions to assess how this report can be revised into a funding proposal. With Iraq and Syria (and Yemen) still classed as FCAS, it is probable that learning generated in Iraq will have direct relevance across the Middle East region. 
All links last accessed June 2017 unless otherwise stated.

1 United Nations Iraq - Joint Analysis Unit (JAU). (2013). Kirkuk, Iraq. Governorate Profile.

2 These aquifers are located at depths of between 20 metres and 200 metres below the surface, with an internal cavity depth of between 300 metres and 850 metres. The three saline aquifers have 4,000-20,000mg/l of total dissolved solids (TDS), according to the Inventory of Shared Water Resources in Western Asia. http://waterinventory.org/groundwater/neogene-aquifer-system-north-west-upper-and-lower-fars (accessed 11 April 2016)

3 J. Vidal (2014)_Water supply key to outcome of conflicts in Iraq and Syria, experts warn. The Guardian. https://www.theguardian.com/environment/2014/jul/02/water-key-conflict-iraq-syria-isis (accessed 3 February 2017)

4 Water security planning is wider than water safety planning, and incorporates aspects of both water quantity and quality.

5 The other disputed governorate is Diyala.

6 Chatham House, (2013). Iraq Ten Years On, London: Royal Institute of International Affairs. https://www.chathamhouse.org/publications/papers/view/191107

7 M. Knights and A. Ali (2010). Kirkuk in Transition: Confidence Building in Northern Iraq. Washington Institute for Near East Policy, Policy Focus \#102. http://www.washingtoninstitute.org/uploads/Documents/pubs/PolicyFocus102.pdf

8 Ibid.

9 Ibid.

10 OCHA (2016). Humanitarian Needs Overview 2016: Iraq. OCHA Iraq Humanitarian Country Team and Partners https://www.humanitarianresponse.info/en/system/files/documents/files/final iraq 2016 hno.pdf (accessed 15 March 2016)

11 FAO AQUASTAT (2008), Iraq. http://www.fao.org/nr/water/aquastat/countries regions/IRQ/ (accessed 15 February 2017)

12 Ibid.

13 Ibid.

14 N.A. Al-Ansari (2013). Management of Water Resources in Iraq: Perspectives and Prognosis. http://dx.doi.org/10.4236/eng.2013.58080

15 FAO AQUASTAT (2008). Iraq, op. cit.

16 Ibid.

17 World Bank (2006). Iraq: Country Water Resource Assistance Strategy: Addressing Major Threats to People's Livelihoods. Water, Environment, Social and Rural Development Department, Middle East and North Africa Region World Bank. http://siteresources.worldbank.org/INTWAT/Resources/lraq.pdf

18 H.K. Al-Jiburi and N.H. Al-Basrawi (2012). Hydrogeology. In: Geology of Low Folded Zone, Iraqi Bulletin of Geology and Mining, Special Issue, No.5, pp.133-157; H.K. Al-Jiburi and N.H. Al-Basrawi (2013). The Hydrogeological Map of Iraq, 2nd edition. Scale 1:1,000,000, Explanatory Text, GEOSURV, int. rep. no. 3434.

19 Ministry of Irrigation (1986). Water Resources and Management of Mesopotamian Plain. These aquifers are located at depths of between 20 metres and 200 metres below the surface, with an internal cavity depth of between 300 metres and 850 metres. The three saline aquifers have 4,000-20,000mg/l of total dissolved solids (TDS), according to the Inventory of Shared Water Resources in Western Asia, op. cit.

20 FAO AQUASTAT (2008). Iraq, op. cit.

21 Ibid.

22 United Nations Development Group (UNDG) (2005). The National Water Master Plan - Phase 1 Water Resources Assessment.

23 EIA (2015). Country Analysis Brief: Iraq. US Energy Information Administration. https://www.eia.gov/beta/international/analysis includes/countries long//raq/iraq.pdf (accessed $20 \mathrm{March} 2016$ )

24 FAO AQUASTAT (2008). Iraq, op. cit.

25 Ibid.

26 UN Economic and Social Commission for Western Asia (ESCWA) (2005). Module 8, Balancing Water Supply and Demand.

27 IOM Iraq (2016). Displacement Tracking Matrix. DTM Round 28 February 2016. International Organisation for Migration (Iraq Mission) Baghdad.

28 United Nations (2013). Water in Iraq Factsheet. UN Iraq Joint Analysis and Policy Unit. http://www.uniraq.com/index.php?option=com k2\&view=item\&id=496:water-in-iraq-factsheet\&ltemid=608\&lang=en

29 M.A.A. Al-Abadi (2013). Water Resources Evaluation of Altun Kopri Basin, near Kirkuk. PhD thesis, College of Science, University of Baghdad. https://www.scbaghdad.edu.iq/library/Geology/PhD/2013/Water resources evaluation.pdf 
30 For an explanation of flood irrigation see: Alliance for Water Efficiency. Flood Irrigation Introduction. http://www.allianceforwaterefficiency.org/Flood Irrigation Introduction.aspx

31 A dunam is a unit of land equivalent to 0.25 hectares or 0.6 acres.

32 UNDP. About Iraq. http://www.iq.undp.org/content/iraq/en/home/countryinfo.html

33 A mukhtar is an unpaid head of a village or suburb who liaises between the community and government.

34 UNHCR (2013). Country Operations Profile - Iraq. http://www.unhcr.org/pages/49e486426.html

35 The Sphere Project (2011). Humanitarian Charter and Minimum Standards in Disaster Response. Geneva. http:// www.sphereproject.org. The Sphere minimum standards (which are currently being updated) require, amongst other things, that each displaced person has $45 \mathrm{~m} 2$ of living space. In reality this space requirement is rarely achieved in humanitarian emergencies and population densities might be much greater.

36 R.C. Carter. (2007). Rapid assessment of groundwater opportunities for displaced and refugee populations. Waterlines Vol 26 No 1 pp2-4, July 2007.

37 Climate-proofing refers to ensuring that current and future development policies, investments or infrastructure are resilient to climate variability and change, reducing climate-related risks to acceptable levels.

38 Citizen science refers to the collection and analysis of data relating to the natural world by members of the general public, typically as part of a collaborative project with professional scientists. 


\section{Oxfam Research Reports}

Oxfam Research Reports are written to share research results, to contribute to public debate and to invite feedback on development and humanitarian policy and practice. They do not necessarily reflect Oxfam policy positions. The views expressed are those of the author and not necessarily those of Oxfam.

(C) Oxfam International August 2017

This publication is copyright but the text may be used free of charge for the purposes of advocacy, campaigning, education, and research, provided that the source is acknowledged in full. The copyright holder requests that all such use be registered with them for impact assessment purposes. For copying in any other circumstances, or for re-use in other publications, or for translation or adaptation, permission must be secured and a fee may be charged. Email policyandpractice@oxfam.org.uk

The information in this publication is correct at the time of going to press.

Published by Oxfam GB for Oxfam International under ISBN 978-0-85598-969-9 in

August 2017. DOI: 10.21201/2017.9699

Oxfam GB, Oxfam House, John Smith Drive, Cowley, Oxford, OX4 2JY, UK.

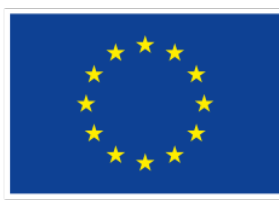

Funded by

European Union

Civil Protection and

Humanitarian Aid

This document covers humanitarian aid activities implemented with the financial assistance of the European Union. The views expressed herein should not be taken, in any way, to reflect the official opinion of the European Union, and the European Commission is not responsible for any use that may be made of the information it contains.

The European Union and its Member States are a leading global donor of humanitarian aid. Through the European Commission's Humanitarian Aid and Civil Protection department (ECHO), the EU helps over 120 million victims of conflict and disasters every year. With headquarters in Brussels and a global network of field offices, ECHO provides assistance to the most vulnerable people solely on the basis of humanitarian needs, without discrimination of race, ethnic group, religion, gender, age, nationality or political affiliation.

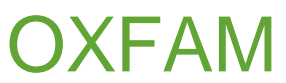

Oxfam is an international confederation of 20 organizations networked together in more than 90 countries, as part of a global movement for change, to build a future free from the injustice of poverty. Please write to any of the agencies for further information, or visit www.oxfam.org 